\title{
Economic Viability of Photovoltaic Systems in a Rural Community in Brazil
}

\author{
Roberto Luiz De Carli ${ }^{1}$, Reginaldo Ferreira Santos ${ }^{1}$, Jair Antonio Cruz Siqueira ${ }^{1}$, \\ Carlos Eduardo Camargo Nogueira ${ }^{1}$, Emmanuelle Albara Zago ${ }^{1} \&$ Luciene Kazue Tokura ${ }^{1}$ \\ ${ }^{1}$ Engineering of Energy in Agriculture, State University of West Paraná, Cascavel, Paraná, Brazil \\ Correspondece: Luciene Kazue Tokura, Engineering of Energy in Agriculture, State University of West Paraná, \\ Rua Universitária, 2069, Jardim Universitário, CEP: 85819-110, Cascavel, Paraná, Brazil. Tel: \\ 55-(45)-3220-3151. E-mail: lucienetokura@gmail.com
}

Received: March 21, 2018

doi:10.5539/jas.v10n7p303

\author{
Accepted: May 14, $2018 \quad$ Online Published: June 15, 2018 \\ URL: https://doi.org/10.5539/jas.v10n7p303
}

\begin{abstract}
Solar energy can be converted directly into electricity using photovoltaic cell technology. It is considered as the technology of the future because it uses the Sun, a clean and inexhaustible source. Thus, this study aimed to evaluate the economic viability in energy generation of a photovoltaic system in a rural community in the district of Rio do Salto. The rural community is in the municipality of Cascavel, western region of the state of Paraná, geographical coordinates latitude $25^{\circ} 8^{\prime} 31^{\prime \prime} \mathrm{S}$, longitude $53^{\circ} 19^{\prime} 40^{\prime \prime} \mathrm{W}$ and altitude $781 \mathrm{~m}$. Rio do Salto has regulations of 19 blocks with 241 properties. The evaluated properties belonged to block 11. The project was feasible when the payback period of the investment occurred within the expected photovoltaic system life cycle and if the internal rate of return (IRR) was higher than the minimum attractiveness expected for the project. To ensure the viability of this power generation system, the average consumption over the 12 -month period should be higher than the rate of availability of the concessionaire that the owner should pay. This value varied according to the connection type (single-phase: $30 \mathrm{kWh}$, two-phase: $50 \mathrm{kWh}$ and three-phase: $100 \mathrm{kWh}$ ). Property 9 was the only one that did not show conditions for photovoltaic system for not reaching the minimum connection tariff of the concessionaire.
\end{abstract}

Keywords: clean energy, energy efficiency system, solar energy

\section{Introduction}

Photovoltaic solar energy is the alternative source with the most attention worldwide. Distributed generation systems are very suitable for installation wherever there is a high incidence of light (Geller, 2003; Villalva \& Gazoli, 2013).

Brazil has great potential to apply photovoltaic solar energy for being favored by high solar irradiation levels; however, this renewable source in the Brazilian market is still quite small (Salamoni, 2009).

According to the Centro de Gestão e Estudos Estratégicos (CGEE) (2010), international documents report to the year 2050 that $50 \%$ of the generation of world will come from renewable sources. Of this demand, $25 \%$ will be supplied photovoltaic solar energy. At the end of this century, this dependency will $90 \%$ of which $70 \%$ will be of photovoltaic origin.

According to ANEEL (2008) and Santos (2013), photovoltaic solar energy is the only one that allows the direct conversion of solar irradiation into electric energy, the most used energy in urban and rural areas. Solar irradiation can be used in three ways: passive solar energy, used through the bioclimatic architecture, which designs the construction to receive the solar incidence to illuminate, warm and direct the air in the internal environments; solar thermal energy, which uses solar irradiation to heat fluids that can be directly used (heating water for consumption in bathrooms, kitchens and laundries) or indirectly (heating fluids to move steam turbines); or photovoltaic solar energy, which directly converts solar irradiation into electric energy.

In rural communities or rural areas, the implantation of photovoltaic systems can provide support for the development of the social, economic, educational, health and financial aspects of numerous rural producers, thus avoiding the need to move to urban centers to access banks, schools, day care centers, health units, among other 
necessities to meet their demands (Corbusier, 2000; Rogner, 2000; Guimarães, 2004; Ultramari, 2005; Ortega, 2008; Almeida \& Soares, 2009).

To install photovoltaic system in rural areas, the measurement data must be performed in places close to where the system is to be deployed, since the radiation incident at each terrestrial site is extremely variable. The connection and customer service, regardless of the size of the rural area, is carried out by ANEEL (2008) and BEN (2014). Pinho (2008) points out that in addition to the regular daily and annual variations due to the apparent movement of the Sun, climatic conditions (clouds) as well as the general atmosphere composition cause irregular variations.

Thus, this work aimed to evaluate the economic viability of photovoltaic power generation systems so that the rural community of Rio do Salto became self-sufficient in the production of energy for local consumption.

\section{Material and Methods}

\subsection{Location Characterization}

The study site was Rio do Salto (geographical coordinates latitude $25^{\circ} 8^{\prime} 31^{\prime \prime} \mathrm{S}$, longitude $53^{\circ} 19^{\prime} 40^{\prime \prime} \mathrm{W}$ and altitude $781 \mathrm{~m}$ ), in the rural area, $32 \mathrm{~km}$ from Cascavel, Western region of the state of Paraná.

The area perimeter is $402,367.84 \mathrm{~m}^{2}$. The area has 19 blocks divided into 241 properties (Perfil Municipal, 2015).

The study area was block 11 dues to the typology of the buildings, rural and social functions, services and housing, pavement of the differentiated streets, location in the middle of the urban area/heat island, presenting differentiated facades and each property having a differentiated ground use.

All constructions in block 11 were evaluated and compared with the information in the municipality database.

\subsection{Monthly Energy Demand in Rio do Salto}

It was made performed the energy demand of Rio do Salto to identify the number of consuming units and their respective consumer classes, and thus to size the photovoltaic generation system to make the site self-sufficient in energy generation.

It was made considered the year 2014 as the basis for energy demand calculations. Data referring to the consumption in $\mathrm{kWh}$ and the number of consuming units (divided by classes), from January to December 2014 were provided by the local electric energy concessionaire (Companhia Paranaense de Energia-COPEL).

It was made evaluated only classes 1 and 3 , which are directly linked to residential and commercial use, respectively.

Therefore, it was made carried out the survey of consumption information only in the buildings of block 11, and based on their annual consumption, it was made performed the analysis between the energy production of the photovoltaic panels with the energy consumption, to the sampling place, and later, it was made defined the average for the implantation in the consumer constructions of class 1 and 3 in the entire district.

To achieve the proposed goal of surveying the energy consumption of the various housing units/energy consuming units, it was made performed several field visits to talk to all the owners, residents or tenants of the research residences, as well as in loco verification of their entrance standards (Figure 1).

The visits took place at the end of March and beginning of April, precisely between March 23rd and April 10th. During this period, it was made identified all consumer units (CU) with their respective CU numbers. 

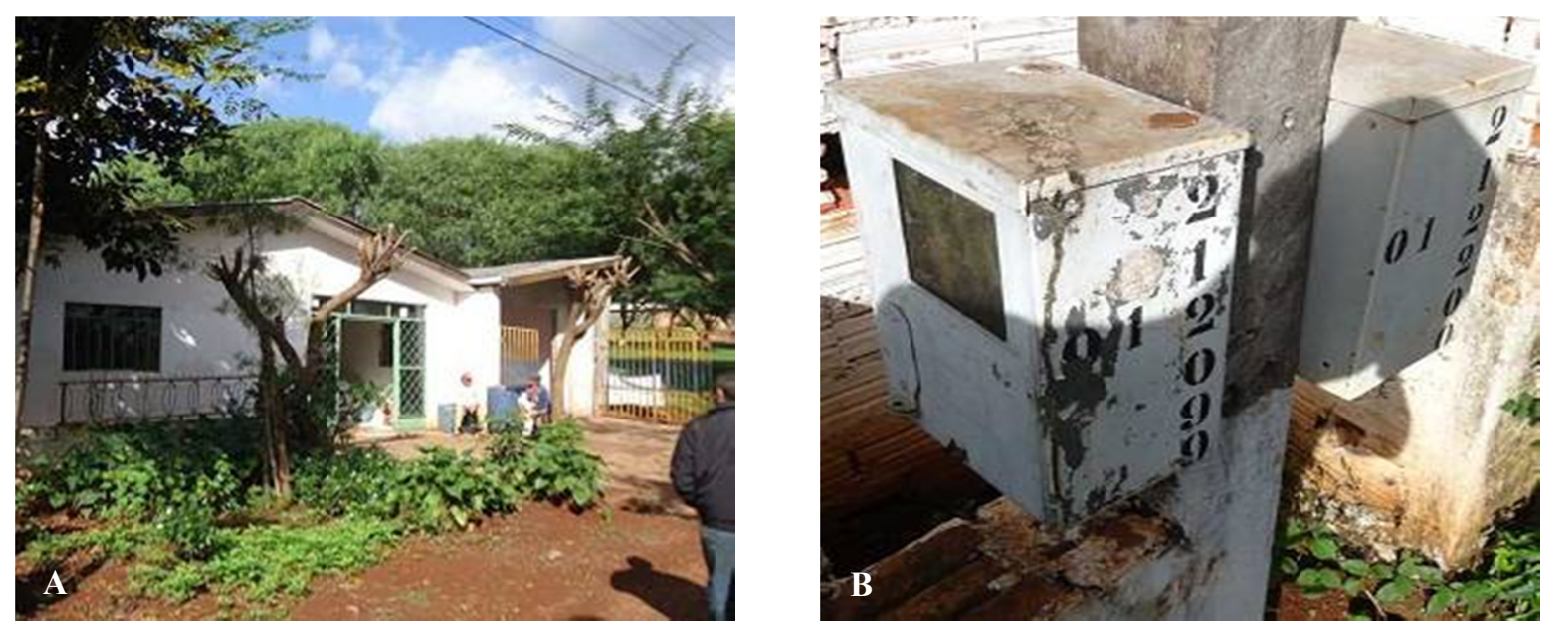

Figure 1. Consumer unit-CU (A) and residence entrance pattern (B)

After identifying the CUs with their respective identification numbers, it was made contacted COPEL to send the collected information and to request the consumption history of these buildings.

With this information, it was made analyzed the consumption of each CU in 2014. Based on this information, the calculations were performed to analyze the feasibility of energy consumption of the buildings.

\subsection{Economic Feasibility Analysis}

The photovoltaic power generation system still has a high cost. According to Pintão (2012), the photovoltaic system value is directly related to the size of its catchment area and to the equipment, therefore it depends on the amount of energy to be generated and the implantation place characteristics, which can cost between 7,000 and $15,000 \mathrm{R} \$ / \mathrm{kWp}$, produced.

Thus, the economic feasibility analysis based on the concepts of the investment analysis. This analysis consisted of estimating all the expenses related to the initial investment for the photovoltaic system implantation. It also included operating, maintenance and revenue expenses generated over a certain period, so that a cash flow could be set up to determine the economic indicators of this system.

As no specific methodology was found for the photovoltaic system economic analysis, with production for consumption and sale of the surplus to the local energy concessionaire (COPEL, energy concessionaire of the State of Paraná) until now, the used investment analysis standard was from ABRAVA (2008). This methodology uses three methods to determine the feasibility of investment and decision-making: Net Present Value (NPV), Discounted Payback Period (DPP) and Internal Rate of Return (IRR).

For the economic feasibility analysis of the study, it was made have only chosen the discounted payback period, with an interest rate of $8 \%$ per year.

\section{Results and Discussion}

During the field survey, it was made verified that the owners have built many properties for renting and/or housing for more family members, justifying the existence of numerous properties within the same property.

Based on this information, it was made decided to carry out the economic feasibility analysis of the photovoltaic system for the property instead of the independent consumer unit.

This is justified because the individual consumption in each consumer unit is often very low, not justifying the implementation of the independent system for each unit. Thus, it was made opted for the system implementation for all existing consumer units in the property, based on the criterion that to have more than one building in a property, it is necessary to create a condominium, as provided for in the Civil Code Art. 1332 (Brasil, 2002) and Federal Law 4591 (Brasil, 1964).

Alienated to the fact that, pursuant to ANEEL (2010a) Resolution 414 (chapter 1, article 2, paragraph III), it provides that there may be a system of energy compensation through a consumer unit with a distributed microregion. This generation would be given to the distributor and subsequently compensated by the 
consumption of other consumer units that have the same ownership, if they have a personal taxpayer registry $(\mathrm{CPF}$, in Portuguese) or a national register of legal entities (CNPJ, in Portuguese) with the Ministry of Finance.

Thus, the proposal to carry out this work, based on the condominium law and ANEEL regulations, proposed to develop microgeneration for each property, and to link them in a single CPF, of the owner of the properties.

\subsection{Energy Demand for Each Property}

The hypothesis was microgeneration unified for each individual property, except for properties 1 and 2, where there was only one residence.

Based on the results, it was made confirmed that the implantation feasibility of photovoltaic systems proved to be advantageous from the moment it is implanted for a set of residences, a factor explicitly demonstrated and identified in the sum of the values, and the average of monthly consumption, since most of them are still low to justify the implementation of photovoltaic assemblies for isolated residences.

To be feasible to install a photovoltaic system, the residence must have at least a two-phase electrical installation; however, to solve this problem, it would be necessary to adapt only one building to install the system, and later through the ANEEL criterion of compensation, to compensate the expenses of other residences, using the condominium system and placing all invoices in a single CPF or CNPJ.

\subsection{Installed Quipment}

For the design of a project and budget proposal with the local company Master Solar, it was made used the Technical Norms of 905,200 (COPEL, 2016), in which standards, equipment, connection types, technical specifications and design are established to develop the micro power generation project for residences.

After preparing the project proposal, it was made looked on the ANEEL (2010) for the list of materials approved by the concessionaire to implement photovoltaic systems for the micro/mini-generation of energy, interconnected to the concessionaire grid in the energy compensation system (grid tie) for buildings.

Thus, the budget based on the calculations and obeying the materials approved by the concessionaire.

Table 1 shows the quantitative summary of the equipment used to install the residential photovoltaic system, stipulated for the properties.

As shown in the Table, the kits offered by the local company are sold in even numbers and are not suitable for all situations.

Thus, the variation of equipment occurs only in the number of photovoltaic panels for energy generation, in relation to the other equipment of the whole photovoltaic assembly. The only difference is that the capacity/load with which they work is larger depending on the number of panels and/or power generation.

Another detail observed when developing the project and budget with the local company is that it works with what it was made can call photovoltaic generation kits; by observing the worksheet, it turns out that in many cases the numbers of photovoltaic panels are repeated, and by analyzing the technical specifications in the budgets presented by it, the technical specifications of the used equipment are standard according to the demand to be generated for each unit, and/or set of consumer units. 
Table 1. Summary of equipment used in residential photovoltaic systems

\begin{tabular}{llllll}
\hline Properties & Inverter & $\begin{array}{l}\text { Photovoltaic } \\
\text { modules }\end{array}$ & String Box & $\begin{array}{l}\text { AC protection } \\
\text { board }\end{array}$ & $\begin{array}{l}\text { Accessories, services } \\
\text { and projects }\end{array}$ \\
\hline 01 and 02 & 1 & 6 & 1 & 1 & 1 \\
03 & 1 & 14 & 1 & 1 & 1 \\
04 & 1 & 6 & 1 & 1 & 1 \\
05 & 1 & 12 & 1 & 1 & 1 \\
06 & 1 & 6 & 1 & 1 & 1 \\
07 & 1 & 6 & 1 & 1 & 1 \\
08 & 1 & 12 & 1 & 1 \\
09 & Not feasible to install the photovoltaic system & 1 & 1 & \\
10 & 1 & 6 & 1 & 1 & 1 \\
11 & 1 & 16 & 1 & 1 & 1 \\
12 & 1 & 12 & 1 & 1 & 1 \\
13 & 1 & 6 & 1 & 1 & 1 \\
14 & 1 & 6 & 1 & 1 & 1 \\
15 & 1 & 6 & 1 & 1 & 1 \\
16 & 1 & 8 & 1 & 1 & 1 \\
17 & 1 & 1 & 14 & 1 & 1 \\
18 & 1 & & & 1 & 1 \\
\hline
\end{tabular}

\subsection{Economic Viability Analysis}

For payback analysis, it was made contacted the company in the city of Cascavel-PR, and it made the budgets available (Master Solar, 2015).

The analysis was performed for a period of 25 years, which corresponds to the life cycle of the photovoltaic system equipment, also considering the reduction of the productivity rate of $0.5 \%$ per year according to the manufacturer's data.

The interest rate for the energy readjustment was considered $15 \%$ for the year 2016 . Predicting a reduction of $2.5 \%$ for subsequent years, the interest rate would be $12.5 \%$ for 2017 and $10 \%$ for 2018 . In 2019, predicting a reduction of $2 \%$, the readjustment would be $8 \%$, and finally stabilizing at an average of $5.5 \%$ from 2020 until 2039 (Newspaper O Globo, 2015).

Based on the values provided by the company, 17 economic analyzes were carried out to verify the feasibility for the implementation in each construction. It is worth mentioning that lots 1 and 2 of this block have a single house.

Figures 2 to 18 show the cash flow for economic feasibility analysis of each lot, with its consuming units.

Pay Back - Lote 01 e 02

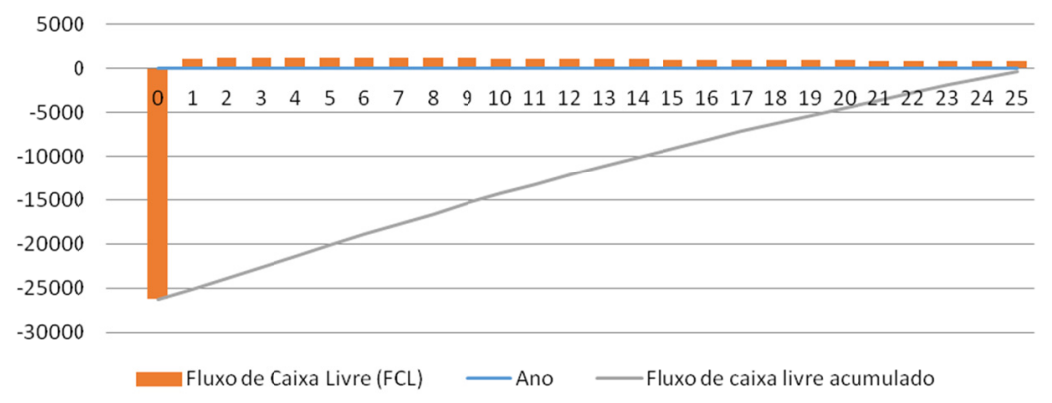

Figure 2. Cash flow of lots 1 and 2 
The economic analysis of the photovoltaic system for a consumer unit with two lots shows an initial investment of R $\$ 26,258.00$. For these lots there would be no return in the period of 25 years and would still have a deficit of R\$ 329.60 at the end of the period.

Payback demonstrates that the installation of the photovoltaic system for these properties is economically interesting.

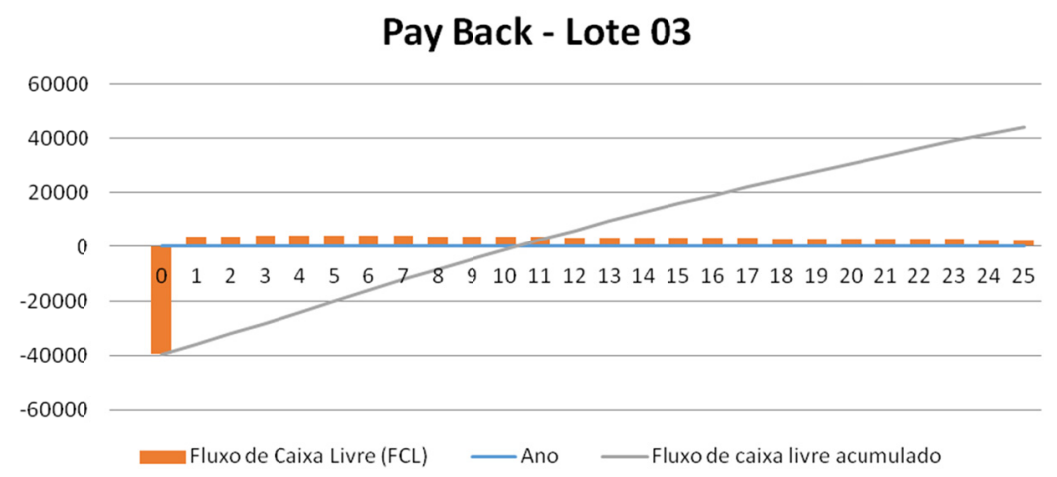

Figure 3. Cash flow of lot 9

The economic analysis of the photovoltaic system for two consumer units in the lot has an initial investment of R\$ 39,562.00, having an expected time return of 10 years and 4 months and a profitability over 25 years of $\mathrm{R} \$ 44,266.66$.

Payback shows that installing the photovoltaic system for these properties is economically viable.

Pay Back - Lote 04

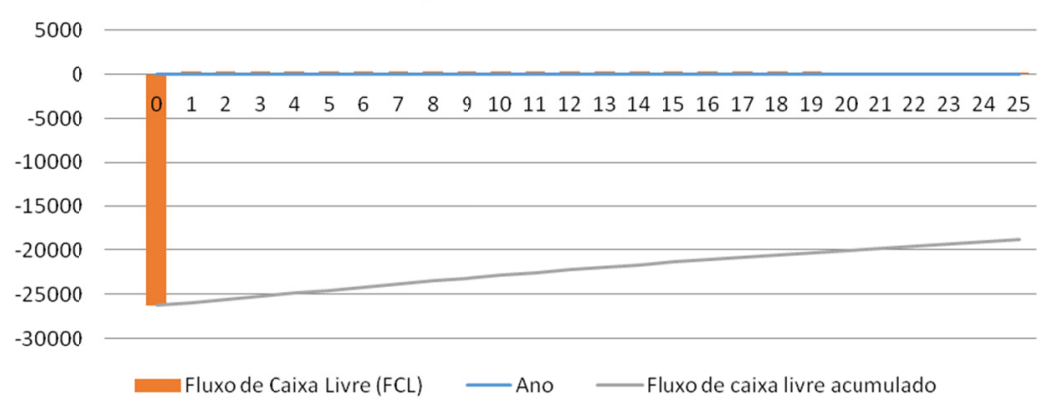

Figure 4. Cash flow of lot 4

The economic analysis of the photovoltaic system for a consumer unit in the lot shows an initial investment of $\mathrm{R} \$ 26,258.00$, with no return for the period of 25 years, as defined, presenting a deficit of $\mathrm{R} \$ 18,849.99$ at the end of the period.

Payback shows that installing the photovoltaic system for these properties is economically unfeasible. 
Pay Back - Lote 05

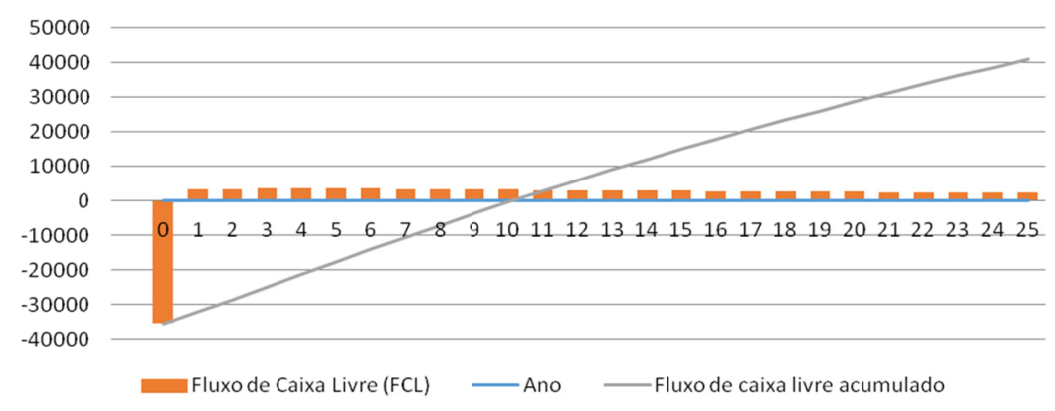

Figure 5. Cash flow of lot 5

The economic analysis of the photovoltaic system with four consumer units in the lot shows an initial investment of $\mathrm{R} \$ 35,377.00$, having a predicted time of return of 10 years and 2 months and a profitability over 25 years of $\mathrm{R} \$ 40,848.59$.

Payback shows that installing the photovoltaic system for these properties is economically viable.

\section{Pay Back - Lote 05}

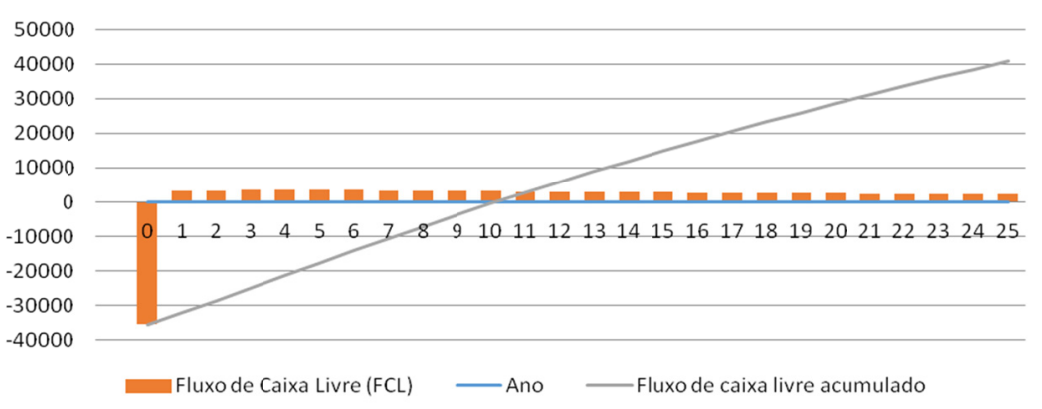

Figure 6. Cash flow of lot 6

The economic analysis of the photovoltaic system for a consumer unit in the lot shows an initial investment of $\mathrm{R} \$ 26,258.00$, with no return for the period of 25 years, as defined, presenting a deficit of $\mathrm{R} \$ 4,033.66$ at the end of the period.

Payback shows that installing the photovoltaic system for these properties is economically unfeasible.

\section{Pay Back - Lote 07}

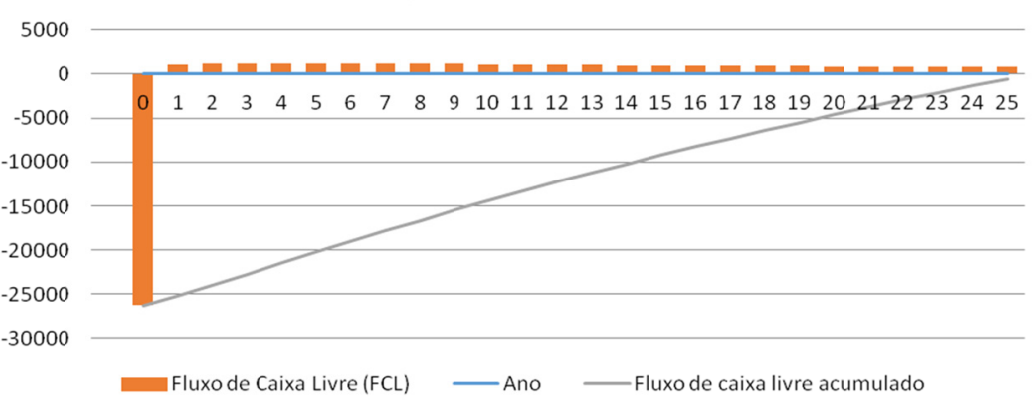

Figure 7. Cash flow of lot 7 
The economic analysis of the photovoltaic system for a consumer unit in the lot shows an initial investment of $\mathrm{R} \$ 26,258.00$, with no return for the period of 25 years, as defined, presenting a deficit of R\$ 524,55 at the end of the period.

Payback demonstrates that the installation of the photovoltaic system for these properties is economically interesting.

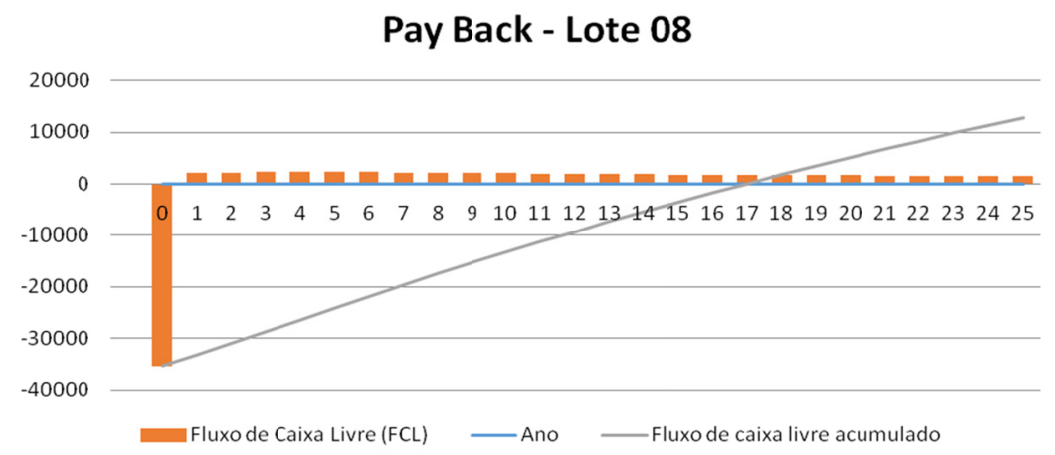

Figure 8. Cash flow of lot 8

The economic analysis of the photovoltaic system with three consumer units in the lot shows an initial investment of $\mathrm{R} \$ 35,377.00$, having a predicted time of return of 16 years and 9 months and a profitability over 25 years of $\mathrm{R} \$ 12,775.74$.

Payback shows that installing the photovoltaic system for these properties is economically viable.

Pay Back - Lote 09

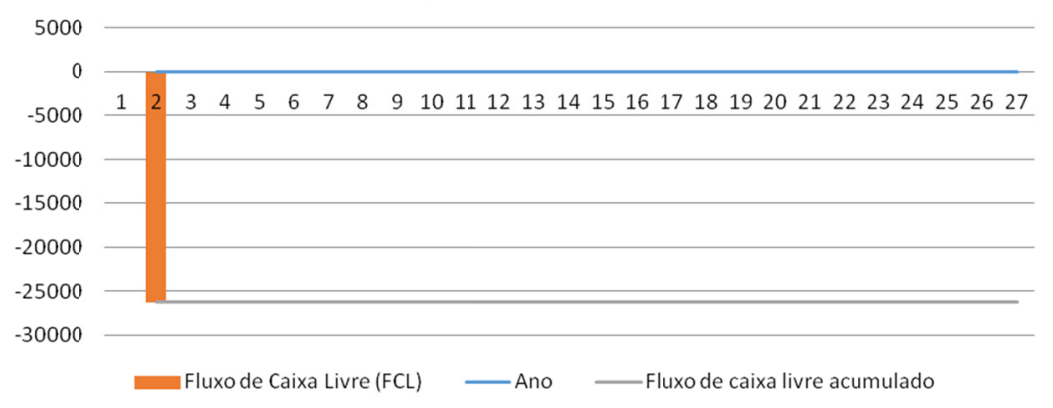

Figure 9. Cash flow of lot 9

The economic analysis of the photovoltaic system for a consumer unit in the lot showed that the energy consumption is equal to or less than the minimum consumption (cost of availability) and the owner would have to pay monthly to the distributor, the values of the minimum rates stipulated for the connection type (two-phase: $50 \mathrm{kWh}$ ), as stipulated in Normative Resolution 414 of ANEEL (2010a). 
Pay Back - Lote 10

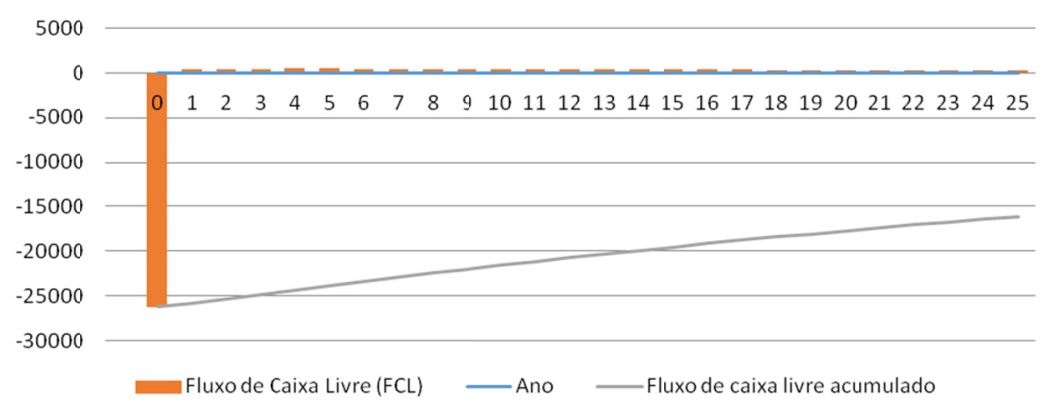

Figure 10. Cash flow of lot 10

The economic analysis of the photovoltaic system for a consumer unit in the lot shows an initial investment of $\mathrm{R} \$ 26,258.00$, with no return for the period of 25 years, as defined, presenting a deficit of $\mathrm{R} \$ 16,120.58$ at the end of the period.

Payback shows that installing the photovoltaic system for these properties is economically unfeasible.

\section{Pay Back - Lote 11}

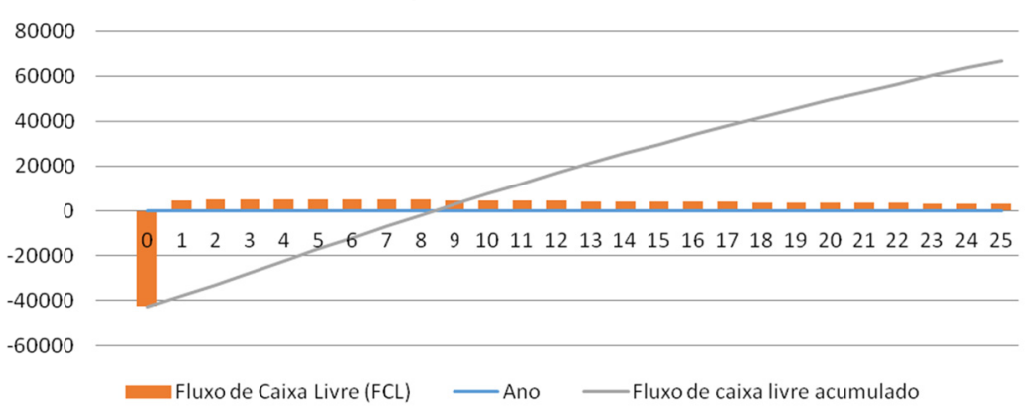

Figure 11. Cash flow of lot 11

The economic analysis of the photovoltaic system for five consumer units in the lot has an initial investment of R \$ 42,800.00, having an expected time return of 8 years and 3 months and a profitability over 25 years of $\mathrm{R} \$ 67,152.01$. While Lu and Yang (2010) found return on investment of 7 years and 3 months, and Chandel et al. (2014) of 7 years and 7 months.

Payback shows that installing the photovoltaic system for these properties is economically viable.

Pay Back - Lote 12

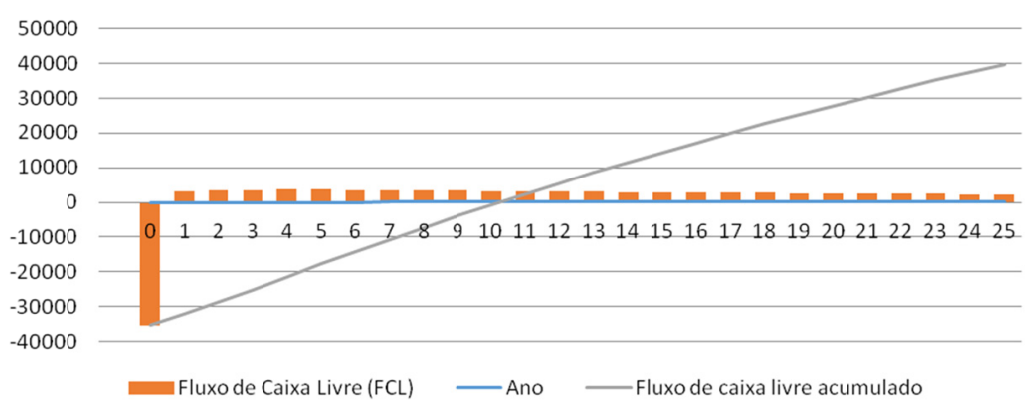

Figure 12. Cash flow of lot 12 
The economic analysis of the photovoltaic system for three consumer units in the lot shows an initial investment of R\$35,380.00, having a predicted time of return of 11 years and 4 months and a profitability over 25 years of $\mathrm{R} \$ 39,773.37$.

Payback shows that installing the photovoltaic system for these properties is economically viable.

\section{Pay Back - Lote 13}

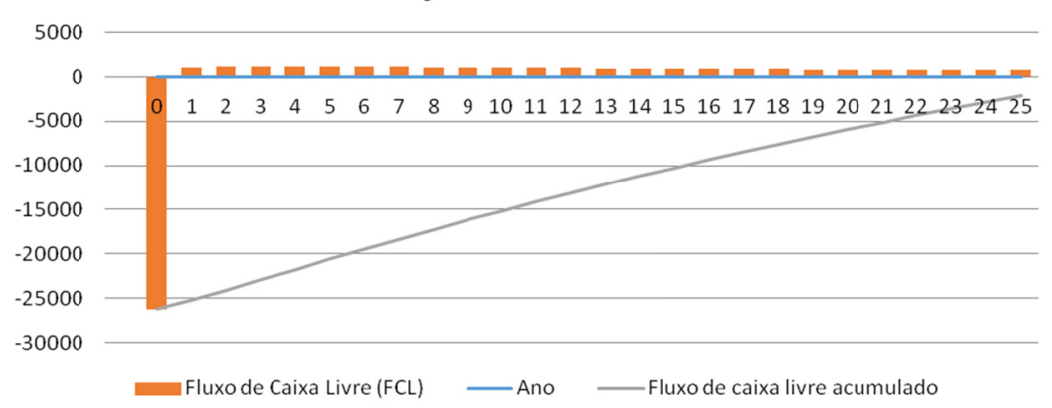

Figure 13. Cash flow of lot 13

The economic analysis of the photovoltaic system for a consumer unit in the lot shows an initial investment of $\mathrm{R} \$ 26,258.00$, with no return for the period of 25 years, as defined, presenting a deficit of $\mathrm{R} \$ 2,084.15$ at the end of the period.

Payback shows that installing the photovoltaic system for these properties is economically unfeasible.

\section{Pay Back - Lote 14}

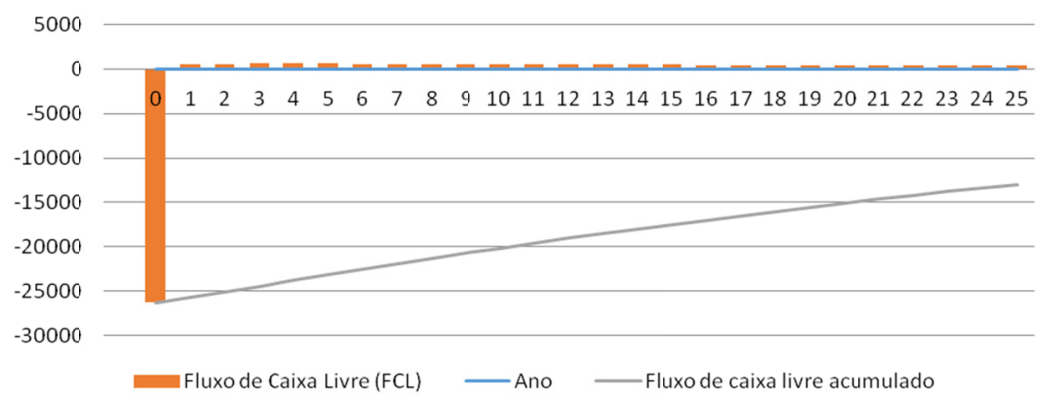

Figure 14. Cash flow of lot 14

The economic analysis of the photovoltaic system for a consumer unit in the lot shows an initial investment of $\mathrm{R} \$ 26,258.00$, with no return for the period of 25 years, as defined, presenting a deficit of $\mathrm{R} \$ 13,001.38$ at the end of the period.

Payback shows that installing the photovoltaic system for these properties is economically unfeasible. 


\section{Pay Back - Lote 15}

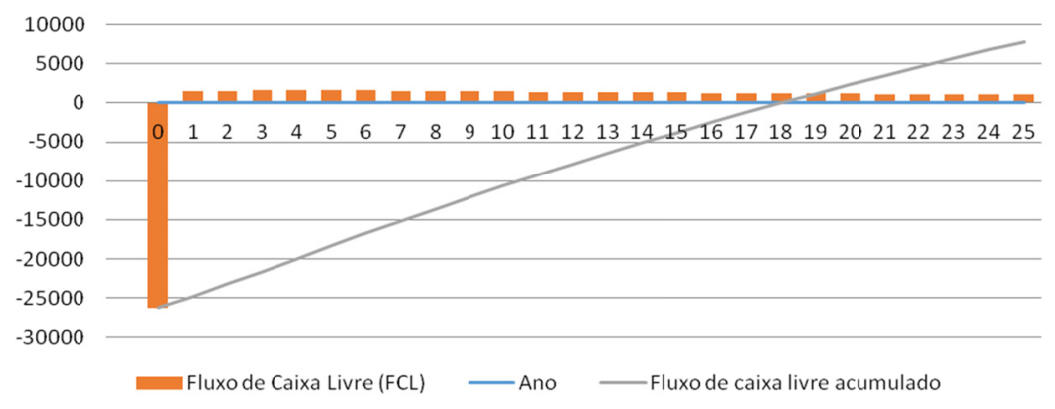

Figure 15. Cash flow of lot 15

The economic analysis of the photovoltaic system for one consumer unit in the lot shows an initial investment of $\mathrm{R} \$ 26,258.00$, having a predicted time of return of 17 years and 11 months and a profitability over 25 years of $\mathrm{R} \$ 7,842.06$.

Payback demonstrates that the installation of the photovoltaic system for these properties is economically interesting.

\section{Pay Back - Lote 16}

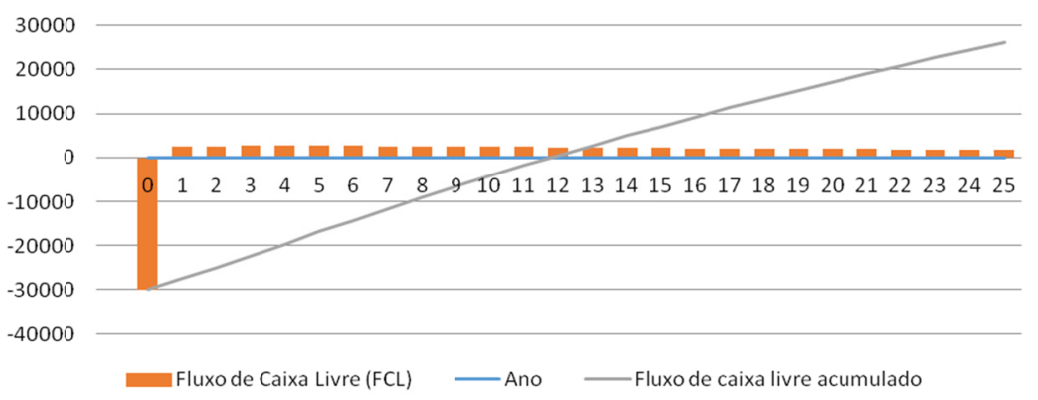

Figure 16. Cash flow of lot 16

The economic analysis of the photovoltaic system for five consumer units in the lot has an initial investment of $\mathrm{R} \$ 30,008.00$, having an expected time return of 11 years and 3 months and a profitability over 25 years of $\mathrm{R} \$ 26,121.46$.

Payback shows that installing the photovoltaic system for these properties is economically viable.

\section{Pay Back - Lote 17}

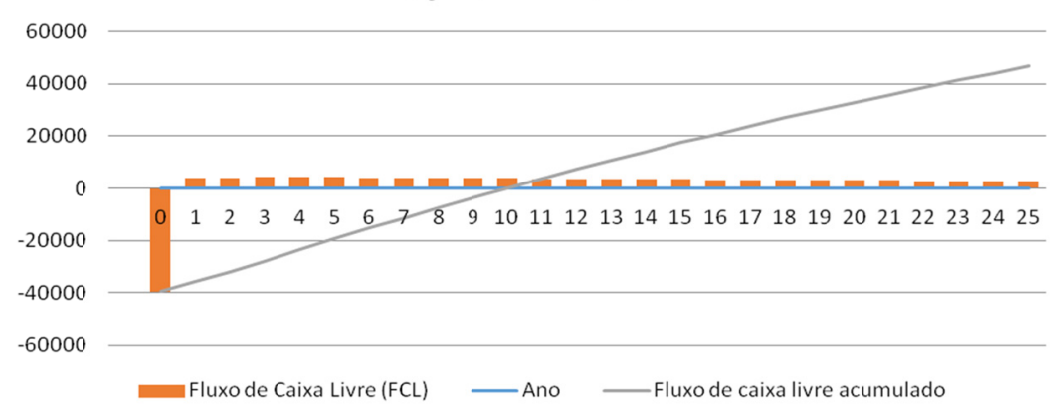

Figure 17. Cash flow of lot 17 
The economic analysis of the photovoltaic system for three consumer units in the lot shows an initial investment of R\$39,562.00, having a predicted time of return of 9 years and 11 months and a profitability over 25 years of $\mathrm{R} \$ 46,784.76$.

Payback shows that installing the photovoltaic system for these properties is economically viable.

Pay Back - Lote 18

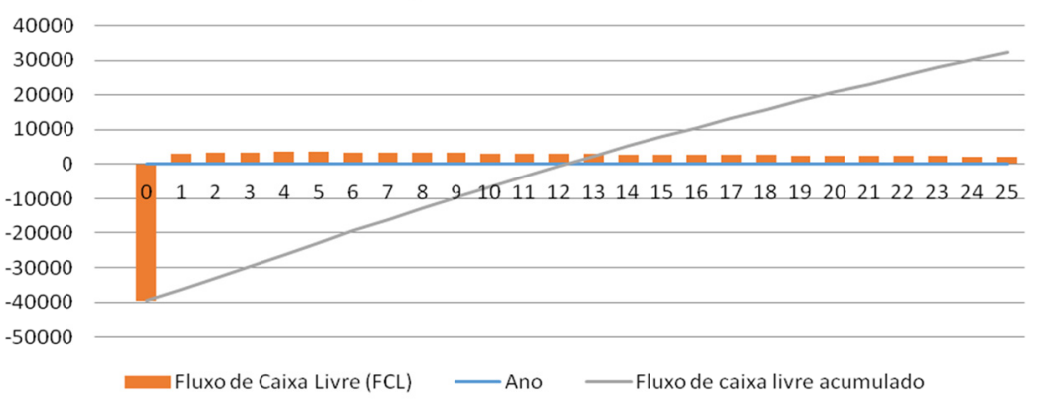

Figure 18. Cash flow of lot 18

The economic analysis of the photovoltaic system for two consumer units in the lot has an initial investment of $\mathrm{R} \$ 39,562.00$, having an expected time return of 12 years and 2 months and a profitability over 25 years of $\mathrm{R} \$ 32,358.44$.

Payback shows that installing the photovoltaic system for these properties is economically viable.

\subsection{Investment Value and Return Time}

Table 2 presents the values to be invested, payback time and value of the investment return over 25 years, when the photovoltaic panels begin to require maintenance, as presented in the budget and in the datasheets of the manufacturers of photovoltaic modules.

Table 2. Identification of the property, payback time, investment value and investment return over 25 years

\begin{tabular}{|c|c|c|c|}
\hline Properties & Payback & $\begin{array}{l}\text { Investment } \\
\text { Value (RS) }\end{array}$ & $\begin{array}{l}\text { Iinvestment Payback } \\
\text { (RS) after } 25 \text { Years-NPV }\end{array}$ \\
\hline 1 and 2 & 0 years and 0 months & $26.258,00$ & 329,60 \\
\hline 3 & 10 years and 4 months & $39.562,00$ & $44.266,66$ \\
\hline 4 & 0 years and 0 months & $26.258,00$ & $18.849,89$ \\
\hline 5 & 10 years and 2 months & $35.377,00$ & $40.848,59$ \\
\hline 6 & 0 years and 0 months & $26.258,00$ & $4.033,66$ \\
\hline 7 & 0 years and 0 months & $26.258,00$ & 524,55 \\
\hline 8 & 16 years and 9 months & $35.377,00$ & $12.775,74$ \\
\hline 9 & 0 years and 0 months & - & - \\
\hline 10 & 0 years and 0 months & $26.258,00$ & $16.120,58$ \\
\hline 11 & 8 years and 3 months & $42.800,00$ & $67.152,01$ \\
\hline 12 & 11 years and 4 months & $35.380,00$ & $39.773,37$ \\
\hline 13 & 0 years and 0 months & $26.258,00$ & $-2.084,15$ \\
\hline 14 & 0 years and 0 months & $26.258,00$ & $-13.001,38$ \\
\hline 15 & 17 years and 11 months & $26.258,00$ & $7.842,06$ \\
\hline 16 & 11 years and 3 months & $30.008,00$ & $26.121,46$ \\
\hline 17 & 9 years and 11 months & $39.562,00$ & $46.784,76$ \\
\hline 18 & 12 years and 2 months & $39.562,00$ & $32.358,44$ \\
\hline Sum & & $507.692,00$ & $262.979,28$ \\
\hline \multicolumn{3}{|c|}{ Average Payback time } & 6 years and 4 months \\
\hline \multicolumn{3}{|c|}{ Investment average } & $\mathrm{R} \$ 29,864.24$ \\
\hline \multicolumn{3}{|c|}{ Average NPV } & $\mathrm{R} \$ 16,436.20$ \\
\hline
\end{tabular}


In all the analyzed properties, except property 9, energy consumption is equal to or less than the minimum consumption that the owner will have to pay monthly to the distributor; all other properties show an attractive profitability for the photovoltaic system implantation.

The average cost for implantation in all housing units and/or isolated consumer unit is $\mathrm{R} \$ 29,864.24$, with average NPV of R $\$ 16,436.20$, and average return time of 6 years and 4 months, for properties in which system deployment is feasible. Property 9 was disregarded from the analysis for not presenting average consumption values higher than the basic energy connection rates with the concessionaire.

Installing the photovoltaic system for a set of residences and/or buildings in rural areas is feasible due to the consumption of each property, that is, it is feasible only for places where energy consumption is high, as in the case of properties $3,5,8,11,12,15,16,17$ and 18 . The implementation is interesting in the unified properties 1 and 2 and property 7 , where at the end of the 25 -year period they are not profitable in the system installation; however, at the end of this period, the outstanding amount to pay off the investment is less than the annual average payback.

The return on investment is much faster due to higher energy consumption of each property, that is, the higher the installed capacity and the shorter the return on investment.

The photovoltaic assemblies (kits) are an economically viable alternative within the proposal of this research of photovoltaic power generation system in a rural community and of the current legislations.

Subsequently, it is suggested suggesting carrying out the feasibility analysis for the photovoltaic system implantation in the whole community, since the implementation of lot 11 was viable.

Installing photovoltaic systems for electric energy generation in the rural community can provide the improvement and maintenance of the activities and services provided in these places.

To ensure the viability of this power generation system, the average consumption over the 12-month period should be higher than the rate of availability of the concessionaire that the owner should pay. This value varies according to the connection type (single-phase: $30 \mathrm{kWh}$, two-phase: $50 \mathrm{kWh}$ and three-phase: $100 \mathrm{kWh}$ ). Property 9 was the only one that did not show conditions for photovoltaic system for not reaching the minimum connection tariff of the concessionaire.

\section{Conclusion}

Properties 3, 5, 8, 11, 12, 15, 16, 17 and 18 showed a return within the stipulated period. The average return of $\mathrm{R} \$ 35,324.79$, oscillating between the maximum return of $\mathrm{R} \$ 46,784.76$ on property 17 and a minimum return of $\mathrm{R} \$ 7,842.06$ on property 15 , with an average variation of $579 \%$ in value among them.

The average payback time is 6 years and 4 months.

The average investment cost for installation of the system is $\mathrm{R} \$ 29,864.24$, ranging from a maximum of $\mathrm{R} \$ 42,800.00$ (system installed in property 11) and a minimum of $\mathrm{R} \$ 26,258.00$ (systems installed in unified properties, 1 and 2).

Properties 4, 6, 10, 13 and 14 are not feasible for photovoltaic system implantation.

\section{References}

ABRAVA (Associação Brasileira de Refrigeração, Ar Condicionado, Ventilação e Aquecimento). (2008). Manual de Capacitação em projetos de aquecimento Solar (p. 138). Retrieved from http://www.forumclima. pr.gov.br/arquivos/File/manual2008.pdf

Almeida, F. G., \& Soares, L. A. A. (2009). Ordenamento territorial: Coletânea de textos com diferentes abordagens no contexto brasileiro. Rio de Janeiro: Bertrand Brasil.

ANEEL (Agência Nacional de Energia Elétrica). (2008). Atlas de energia elétrica do Brasil (3rd ed.). Agência Nacional de Energia Elétrica. Brasília: ANEEL.

ANEEL (Agência Nacional de Energia Elétrica). (2010). Resolução Normativa nº 482, de 17 de Abril de 2012. Retrieved from http://www.aneel.gov.br/cedoc/ren2012482.pdf

ANEEL (Agência Nacional de Energia Elétrica). (2010a). Resolução Normativa $n^{\circ} 414$, de 9 de Setembro de 2010. Agência Nacional de Energia Elétrica. Retrieved from http://www.aneel.gov.br/cedoc/bren20104 14.pdf

BEN (Balanço Energético Nacional). (2014). Relatório Final do Balanço Energético Nacional 2014. Empresa de Pesquisa Energética. Retrieved from https://ben.epe.gov.br 
Brasil. (1964). Dispõe sobre condomínio e incorporações imobiliárias. Lei Número 4.591, de 16 de Dezembro de 1964. Retrieved from http://www.planalto.gov.br/ccivil_03/leis/L4591.htm

Brasil. (2002). Artigo 1332 do Codigo Civil. Lei Número 10406, de 10 de Janeiro de 2002. Retrieved from http://www.jusbrasil.com.br/topicos/10646207/artigo-1332-da-lei-n-10406-de-10-de-janeiro-de-2002

CGEE (Centro de Gestão e Estudos Estratégicos). (2010). Energia solar fotovoltaica no Brasil: Subsídios para tomada de decisão (Série Documentos Técnicos 02-10). Brasília, Distrito Federal: Centro de Gestão e Estudos Estratégicos.

Chandel, M., Agrawal, G. D., Mathur, S., \& Mathur, A. (2014). Techno-economic analysis of solar photovoltaic power plant for garment zone of Jaipur city. Case Studies in Thermal Engineering, 2, 1-7, https://doi.org/ 10.1016/j.csite.2013.10.002

COPEL (Companhia Paranaense de Energia). (2016). Normas técnicas Copel. NTC 905200. Acesso de micro e minigeração distribuída ao sistema da COPEL, Curitiba, Paraná. Retrieved from https://copel.com

Corbusier, L. (2000). Urbanismo (2nd ed.). São Paulo: Martins Fontes.

Geller, H. S. (2003). Revolução energética: Políticas para um futuro sustentável. Rio de Janeiro: USAid.

Guimarães, P. P. (2004). Configuração urbana: Evolução, avaliação, planejamento e urbanização. São Paulo: ProLivros.

Lu, L., \& Yang, H. X. (2010). Environmental payback time analysis of a roof-mounted building-integrated photovoltaic (BIPV) sustem in Hong Kong. Applied Energy, 87, 3625-3631, https://doi.org/10.1016/ j.apenergy.2010.06.011

Master Solar Energy Ltda. (2015). Energia Sustentável. Proposta Comercial e de Serviços. Retrieved from http://www.mastersolar.com.br

Newspaper O Globo. (2015). Cadernos da edição de Janeiro de 2015. Retrieved from http://www.acervo.oglobo. globo.com/consulta-ao-acervo/?navegaçãoporData=201020150101

Ortega, A. C. (2008). Territórios deprimidos: Desafios para as políticas de desenvolvimento rural. Campinas: Alínea.

Perfil Municipal. (2015). Perfil do Municipio de Cascavel. Retrieved from http://www.cascavel.pr.gov.br/secre tarias $/$ seplan/pagina.php?id $=202$

Pinho, J. T. (2008). Sistemas híbridos: Soluções energéticas para a Amazônia (1st ed.). Brasília: Ministério de Minas e Energia. Retrieved from https://www.mme.gov.br/luzparatodos/downloads/Solucoes_Energeticas_ para_a_Amazonia_Hibrido

Pintão, R. A. (2012). Entra em vigor norma que permite produzir energia e vender excedente. Revista Sustentabilidade. Retrieved from http://revistasustentabilidade.com.br/entr-em-vigor-norma-que-permiteproduzir-energia-e-vender-excedente

Rogner, H. (2000). World Energy Assessment: Energy and the Challenge of Sustainability. World Energy Council, London, UK.

Salamoni, I. T. (2009). Um programa residencial de telhados solares para o Brasil: Diretrizes de políticas públicas para a inserção da geração fotovoltaica conectada à rede elétrica (Tese de doutorado em Engenharia Civil, Universidade Federal de Santa Catarina, Florianópolis).

Santos, I. P. (2013). Desenvolvimento de ferramenta de apoio à decisão em projetos de integração solar fotovoltaica à Arquitetura (Tese de Doutorado, Universidade Federal de Santa Catarina, Centro Tecnológico. Programa de Pós Graduação em Engenharia Civil, Florianópolis).

Ultramari, C. (2005). O fim das utopias urbanas. São Paulo: Studio Nobel.

Villalva, M. G., \& Gazoli, J. R. (2013). Energia solar fotovoltaica: Conceitos e aplicações. Sistemas Isolados e Conectados à Rede (1st ed.). São Paulo: Érica.

\section{Copyrights}

Copyright for this article is retained by the author(s), with first publication rights granted to the journal.

This is an open-access article distributed under the terms and conditions of the Creative Commons Attribution license (http://creativecommons.org/licenses/by/4.0/). 